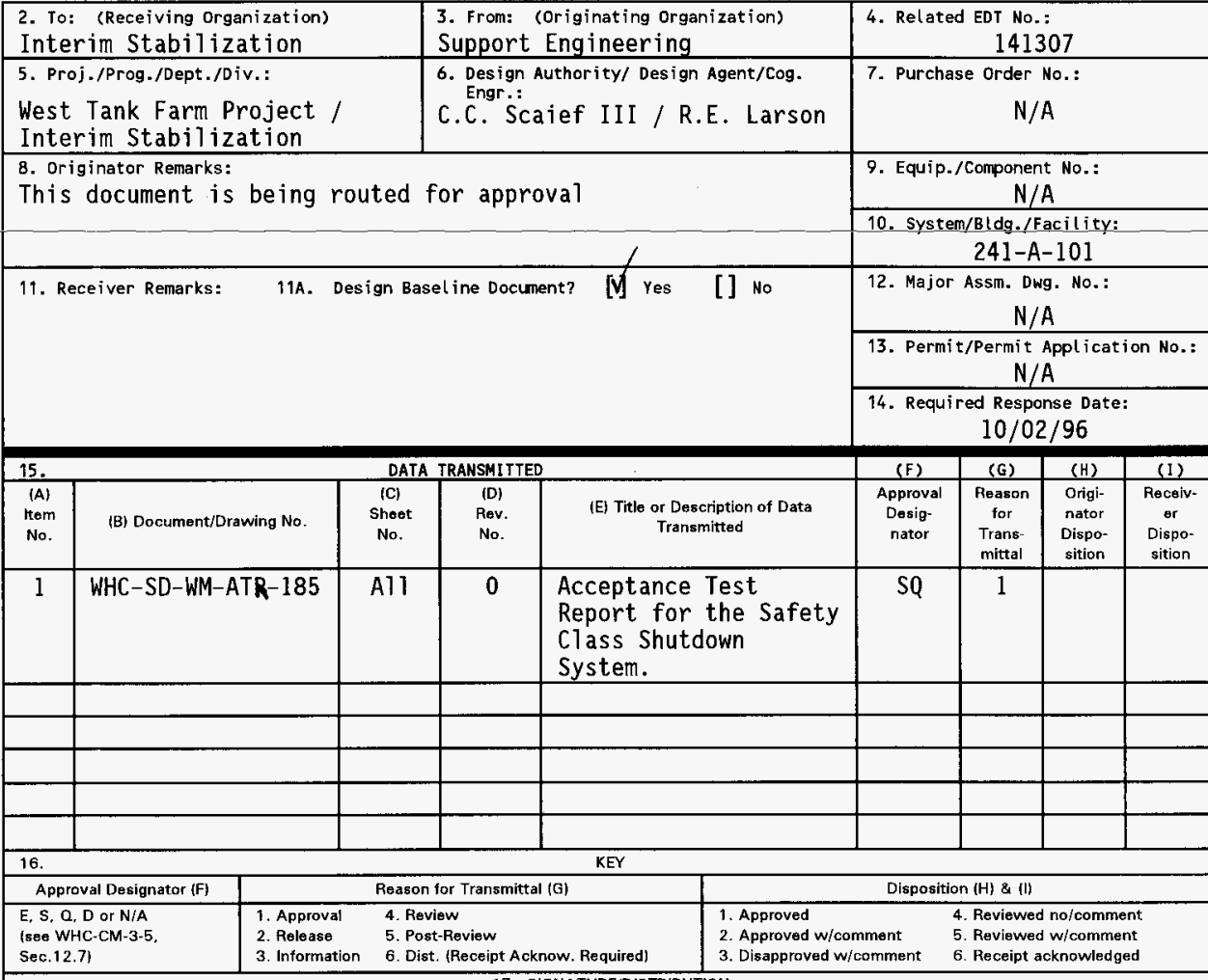

17. SIGNATURE/DISTRIBUTION

(Seo Approval Designator for required signatures)

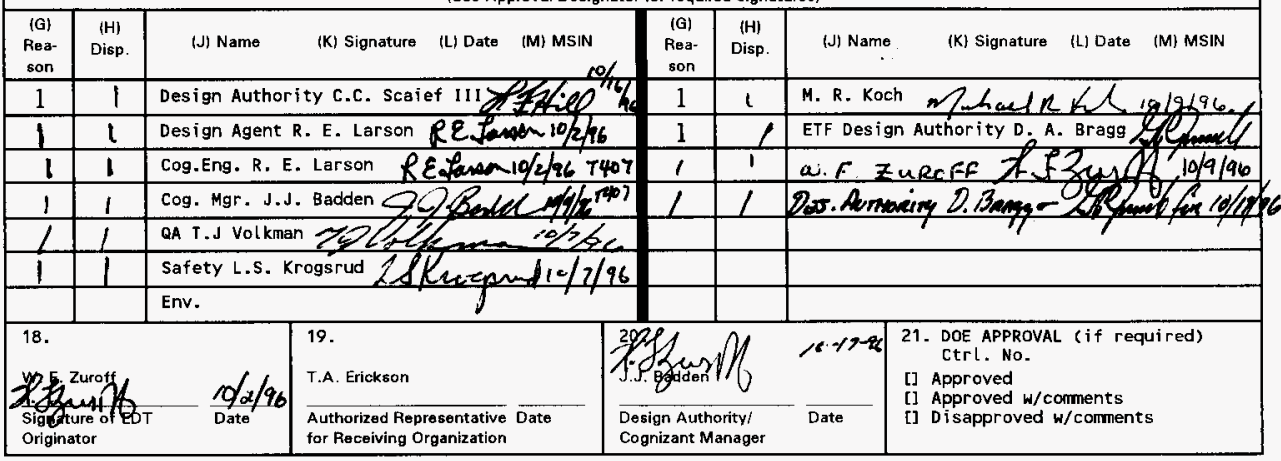




\section{ACCEPTANCE TEST REPORT FOR THE SAFETY CLASS SHUTDOWN SYSTEM}

W. F. Zuroff

Lockheed Martin Hanford Company, Richland, WA 99352

U.S. Department of Energy Contract DE-AC06-87RL10930

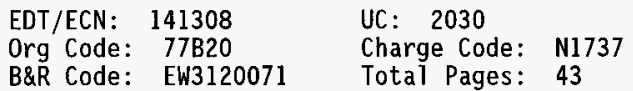

Key Words: 241-A-101; Interim Stabilization; Jet Pumping; Single She11 Tanks; Safety Shutdown Circuit; Safety Class; Saltwell Pumping

Abstract: This document provides the Acceptance Test Report for the successful testing of the Safety Shutdown Circuit. The test was done in accordance with the requirements that were defined in WHC-SD-WM-SCH-003, Interim Stabilization Safety Class Trip Circuit CGI Dedication Criteria. The actual test procedure document was contained in WHC-SD-WM-ATP-185, Acceptance Test Procedure for the Safety Class Shutdown System.

TRADEMARK DISCLAIMER. Reference herein to any specific comercial product, process, or service by trade name, trademark, manufacturer, or otherwise, does not necessarily constitute or imply its endorsement, recomendation, or favoring by the United States Government or any agency thereof or its contractors or subcontractors.

Printed in the United States of America. To obtain copies of this document, contact: WHC/BCS Document Control Services, P.0. Box 1970, Mailstop H6-08, Richland WA 99352, Phone (509) 372-2420; Fax (509) 376-4989.
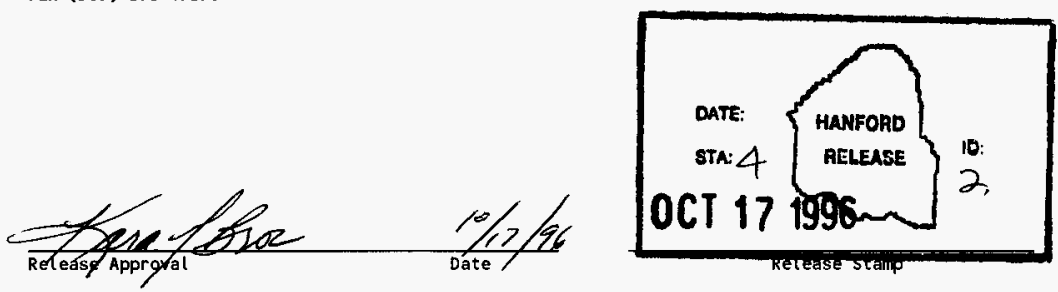

\section{Approved for Public Release}




\section{ACCEPTANCE TEST REPORT FOR THE SAFETY CLASS SHUTDOWN SYSTEM}




\subsection{PURPOSE}

The purpose of this report is to document the results of the acceptance testing that was performed on the safety class shutdown system in accordance with WHC-SD-WM-ATP-185, Acceptance Test Procedure for the Safety Class Shutdown System. A copy of the completed test is attached to this report.

\subsection{DISCUSSION}

The test was performed by Westinghouse Hanford Company personnel using work package ES-96-00704, 241-A-101 Perform ATP on Safety Shutdown System. The test commenced on $8 / 21 / 96$. The test demonstrated the equipment functioned as designed and in accordance with the test procedure.

This test demonstrated the acceptance of the Safety Class (SC) Commercial Grade Items (CGI) as required by WHC-SD-WM-SCH-003, INTERIM STABILIZATION SAFETY CLASS TRIP CIRCUIT CGI DEDICATION CRITERIA.

The testing resulted in seven minor exceptions to the test document. All exceptions have been properly resolved and dispositioned.

The shutdown system performed very well and had an excellent time response time of less than 10 milliseconds. All components functioned as expected except the mercury switches. The switches are designed to operate in only one direction. This feature required the addition of two more switches (one for the X-plane and one for the Z-plane).

\subsection{CONCLUSION}

The system functioned as designed. It has been installed and is awaiting the Operational Test that will be performed in conjunction with all the equipment installed to support the saltwell pumping of SingleShel1 Tank 241-A-101.

\section{ATTACHMENT}

A copy of the completed Acceptance Test Procedure is attached to this document. It includes all exceptions with the required disposition. 


\title{
ACCEPTANCE TEST REPORT \\ FOR THE SAFETY CLASS SHUTDOWN SYSTEM
}

\author{
ATTACHMENT
}




\section{TABLE OF CONTENTS}

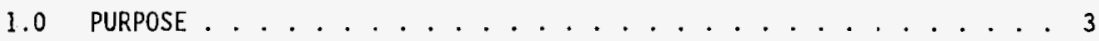

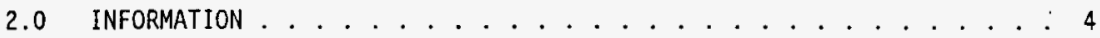

2.1 SCOPE . . . . . . . . . . . . . ... 4

2.2 TERMS AND DEFINITIONS ................ 7

2.3 RESPONSIBILITIES . . . . . . . . . . . . . . . . 7

2.4 REFERENCES .................... . . . 8

2.5 SAFETY . . . . . . . . . . . . . . 8

2.6 RADIATION AND CONTAMINATION CONTROL ...........

2.7 Qualitr ASSURANCE . . . . . . . . . . . . . . . . 9

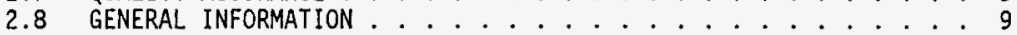

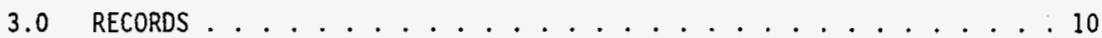

4.0 PREREQUISITES . . . . . . . . . . . . . . . 11

5.0 PROCEDURE . . . . . . . . . . . . . . . . 12

5.1 MERCURY SWITCHES FUNCTIONAL TEST . . . . . . . . . . . 12

5.2 DIFFERENTIAL PRESSURE RELAY FUNCTIONAL TEST. . . . . . . . . . .

5.3 FLAMMABLE GAS MONITOR INPUT SIGNAL FUNCTIONAL TEST . . . . . . .16

5.4 VENTILATION SKID FLOW INPUT SIGNAL FUNCTIONAL TEST $\ldots . . . .20$

5.5 CONTACTORS FUNCTIONAL TEST AND SHUTDOWN SYSTEM TIME RESPONSE - .21

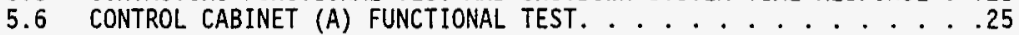

\section{FIGURES}

FIGURE 5.1 SAFETY CLASS CONTROL CABINET A .............. 28

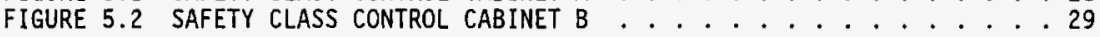

DATA FORMS

DATA SHEET LOG ..................... . . 30

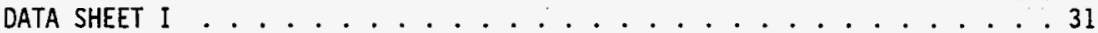

\section{EXCEPTION FORMS}

ATP EXCEPTION LOG . . . . . . . . . . . . . . . . . . . 32

ATP EXCEPTION RECORD . . . . . . . . . . . . . . . . . . 33

ATP ACCEPTANCE RECORD . . . . . . . . . . . . . . . . 34

PROCEDURE HISTORY SIGNATURE SHEET . . . . . . . . . . . . 35 


\subsection{PURPOSE}

1.1 This ATP will test and verify the operability of the safety class shutdown system to be located at 241-A-101, in support of the A-101 saltwell jet pumping campaign.

Systems/checks that will be tested/performed include the following:

- Mercury Switches Functional Test

- Differential Pressure Relay Functional Test

- Flammable Gas Monitor Input Signal Functional Check

- Ventilation Skid Flow Input Signal Functional Check

- Contactors (PMP-1, PMP-2, HT-1 and HT-2) Functional Check and Shutdown System Time Response

- Control Cabinet (A) Switches Functional Test

- Control Cabinet (B) Switch and Indicating Lights Functional Check

- Output Signals to PICS Skid Functional Check

1.2 This ATP will NOT check the operability of the following equipment that is to be or has been tested via other test procedures;

- Portable Ventilation Flow Relay Operation

- Flammable Gas Relay Operation

- Dome Pressure Transmitter Operation

- Input Signal Cables (checked by the field installation crew) 


\subsection{INFORMATION}

\section{$2: 1 \quad$ SCOPE}

\subsubsection{MERCURY SWITCHES FUNCTIONAL TEST}

This test will verify the two mercury switches actuate when the cabinets are shaken in the $X$ and $Z$ planes (similar to a seismic event). A check of the switch continuity (i.e., a voltmeter across the each switch) shall be performed during the switching function. The relay actuated by the mercury switches is relay $\mathrm{K} 3$. This test will also verify the operation of this relay. The three input signals received from other devices will have to be simulated to allow this test to be performed.

Once the mercury switches operate the "Seismic" reset button shall be used to reset the shutdown circuitry.

\subsubsection{DIFFERENTIAL PRESSURE RELAY FUNCTIONAL TEST}

The pressure relay functional test shall be performed by providing a 4-20ma input signal to the isolator relay. The input signal shall be varied between 4 and $20 \mathrm{ma}$. When the setpoint is reached the differential pressure relay will open causing the shutdown circuit to function. The relays actuated by this input signal are relays $\mathrm{Kl}$ and $\mathrm{K} 2$. This test will also verify the operation of these relays.

Once the differential pressure switch operates the "Panel" reset button shall be used to reset the shutdown circuitry.

\subsubsection{FLAMMABLE GAS MONITOR INPUT SIGNAL FUNCTIONAL CHECK}

The flammable gas monitor (FGM) input signal functional check shall be tested by installing a light switch wired across the input signal terminals. The switch shall be opened and closed to ensure the safety shutdown circuitry operates correctly. The relays actuated by this input signal are relays $K 1$ and $K 2$. This test will also verify the operation of these relays.

Once the FGM test switch operates the "Panel" reset button shall be used to reset the shutdown circuitry. 


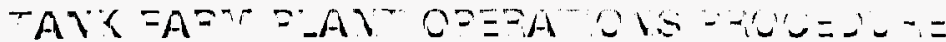

2.1 :SCCPE (cont)

מ. 1.t VENTILATION SKID FLOW INPUT SIGNAL FUNCTIONAL CHECK

The ventilation skid flow input signal functional check shall be tested by installing a light switch wired across the input signal terminals. The switch shall be opened and closed to ensure the safety shutdown circuitry operates correctly. The relays actuated by this input signal are relays KI and K2. This test will also verify the operation of these relays.

Once the flow test switch operates the "Panel" reset button shall be used to reset the shutdown circuitry.

2.1.5 CONTACTORS (PMP-1, PMP-2, HT-1 and HT-2) FUNCTIONAL CHECK and SHUTDOWN SYSTEM TIME RESPONSE

A check of contactors functioning properly shall be verified during the tests performed via steps 2.1.2, 2.1.3 and 2.1.4. The operation of the safety class shutdown system will be timed from the time the input signal actuates to the time the contactors drop out. The time needs to be less than or equal to one second (re-perform step 2.1 .3 or 2.1 .4 , as required).

Once the input signal actuates the "Panel" reset button shall be used to reset the shutdown circuitry.

2.1.6 CONTROL CABINET (A) SWITCHES FUNCTIONAL TEST

A check of the Manual Shutdown/Test pushbutton must be accomplished. Simulated input signals shall be provided for the cabinet to function properly. The switch shall be pressed to initiate a shutdown.

Once the switch actuates the contactors the "Panel" reset button shall be used to reset the shutdown circuitry.

\subsubsection{CONTROL CABINET (B) SWITCH and INDICATING LIGHTS FUNCTIONAL} CHECK

A check of the Seismic Reset pushbutton must be accomplished. Simulated input signais shall be provided for the cabinet to function properly. The structure shall be shaken to initiate a shutdown.

Once the relay actuates the contactors the "Seismic" reset button shall be used to reset the shutdown circuitry. this portion of the system will be checked as part of the scope of Section 2.1.2.

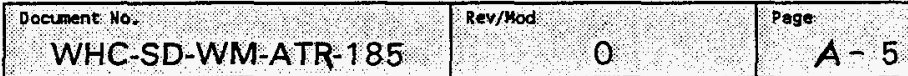




\subsection{SCOPE (cont.)}

2.1.8 OUTPUT SIGNALS TO PICS SKID FUNCTIONAL CHECK

A check of the $K 3$ relay output signal must be accomplished when the mercury switches have operated (de-energizing the K3 relay coil). A check of the motor power contactors (PMP-1 and PMP-2) auxiliary contact, for indication of the shutdown circuitry functioning, to the PICS skid is required. When a shutdown occurs verify these auxiliary contacts open.

Once the $\mathrm{K} 3$ relay actuates the contactors the "Seismic" reset button shall be used to reset the shutdown circuitry. Once the $\mathrm{K} 1$ and/or $\mathrm{K} 2$ relay actuates the contactors the "Panel" reset button shall be used to reset the shutdown circuitry.

The K-3 relay output signal will be checked as part of the scope of Section 2.1.1. The PMP-1 and PMP-2 auxiliary contacts will be checked as part of the scope of Section 2.1 .5 . 


\section{TANK FARıI PLANT OPERATIONS .'ROCEDURE}

\subsection{TERMS AND DEFINITIONS}

2.2.1 ATP - Acceptance Iest Procedure

2.2.2 ATR - Acceptance Iest Report

2.2.3 DPM - Differential Pressure Monitor

2.2.4 ma - millii-ampere

2.2.5 msec - milli-second

2.2.6 JHA - Job Hazards Analysis

2.2.7 QC - Quality $\underline{\text { Control }}$

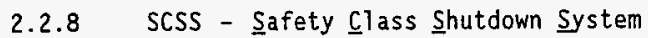

2.2.9 TFO - Iank Earm Qperations

2.2.10 VAC - Voltage Alternating Current

\subsection{RESPONSIBILITIES}

2.3.1 The Maintenance craft personnel are responsible for:

- Providing assistance during the test.

2.3.2 Quality Control (QC) is responsible for:

- Verifying that this procedure was performed, all sections were completed and the documentation properly filled out or an exception written. Witnessing of certain procedure steps will be required. 
2.3 RESPONSIBILITIES (cont.)

\subsubsection{Test Director}

- Provides concurrence that ATP may commence.

- Ensures the equipment found in step 4.1 of this procedure is available.

- Records equipment status and data per this procedure.

- Conducts a pre-job planning meeting.

- Conducts a Safety Class Shutdown System walkdown.

- Verifying Tank Farms Maintenance Crafts are in-place prior to commencing the ATP.

- Notifying the TFO Shift Manager of intent to start this procedure before commencing the ATP.

\subsection{REFERENCES}

2.4.1 The following documents were used to write or are referenced in this procedure:

- WHC-CM-1-10, SAFETY MANUAL, WKS-6, "PRE-JOB SAFETY PLANNING," WKS-8.1, "OPERATIONS LOCK AND TAG PROGRAM," WKS-15, "ELECTRICAL WORK SAFETY"

- WHC-CM-4-2 QR 11.0, QUALITY ASSURANCE MANUAL "TEST CONTROL"

- WHC-CM-6-1 EP 4.2., STANDARD ENGINEERING PRACTICE "TESTING PRACTICES"

- WHC-CM-6-1 APPX M, STANDARD ENGINEERING PRACTICES "ACCEPTANCE TEST PROCEDURES AND REPORTS".

- ECN-632817, SAFETY CLASS SHUTDOWN CIRCUIT

- WHC-SD-WM-SCH-003, INTERIM STABILIZATION SAFETY CLASS TRIP CIRCUIT CGI DEDICATION CRITERIA

\subsection{SAFETY}

\section{WARNING}

Energized circuits and leads are contained inside the equipment.

Observe appropriate electrical precautions. Comply with WHC-CM-1-10, WKS-15, ELECTRICAL WORK SAFETY. 


\subsection{SAFETY (cont.)}

2.5.1 The following administrative procedures control work performed in this procedure:

- Building Emergency Plan, WHC-IP-0263-TF

- Industrial Hygiene Manuals, WHC-CM-4-40 and 1-11

- Safety ManuaI, WHC-CM-1-10

- Tank Farm Heaith and Safety Plan (HASP), WHC-SD-WM-HSP-002

\subsection{RADIATION AND CONTAMINATION CONTROL}

2.6.1 HPT assistance is not required as the test is being performed in the assembly shop.

2.6.2 The following administrative procedures control work performed in this procedure:

- Safety Manual, WHC-CM-1-10

\subsection{QUALITYASSURANCE}

2.7.1 Ensure that the check(s)/test(s) are performed per procedure. The QC Inspector shall sign and date each procedure section authenticating the validity of the data (if any) obtained and verifying that the procedure section has been performed and documented correctly.

\subsection{GENERAL INFORMATION}

2.8.1 Complete each procedure step in the given order, unless otherwise noted or as directed by the Test Director.

2.8.2 Editorial changes required to this ATP may be made per the red line method by the Test Director and Cognizant Engineer as long as they do not impact the equipments safety function, or performance and will not compromise or influence the test data. Any changes affecting the above stated criteria shall be made in accordance with WHC-CM-6-1, Standard Engineering Practices, EP-2.2 Change Control. 


\subsection{GENERAL INFORMATION (cont.)}

2.8.3 All entries recorded in this procedure shall be made in black ink except for those noted using the redline method.

2.8.4 Any non-conformance of the equipment or unexpected resuits during testing shall be logged and recorded in ATP EXCEPTION LOG.

2.8.5 Do not perform any part of this procedure on faulty equipment. If faulty equipment is discovered, STOP the execution of this procedure and resolve the problem (i.e. repair equipment or write up faulty equipment as an exception and continue).

2.8.6 If the performance of this procedure is suspended for any reason, ensure the requirements of the Lock and Tag System are met before leaving the test site.

2.8.7 At the completion of daily ATP testing, ensure that the equipment is returned to a safe configuration.

2.8.8 This procedure DOES contain separate data/ verification sheets. Reference to data sheets are incorporated into the specific section.

2.8.9 The equipment has no interfaces with other equipment (other than the test equipment) for the purposes of this test.

2.8.10 A JHA form will be used in conjunction with the Prejob safety meeting form when any unusual hazards are identified. The PRE-JOB SAFETY MEETING FORM will be used with the JHA to document all attendees.

\subsection{RECORDS}

3.1 The completed working copy of this ATP, data sheets and all exception logs and exception records generated by this ATP, will be kept as permanent records and released in an ATR. 


\subsection{PREREQUISITES}

4.1 The following supplies shall be available at the workplace:

- 15 Amp (min.) light switches (2)

- Calibrated 4-20ma current 10op source

- Calibrated Multimeter(s)

- Shorting jumpers \#12 AWG SIS or engineering approved equal, length as required

- 250 OHM resistor, $1 / 2$ watt

- Calibrated Multi-channel event recorder (or equivalent)

4.2 The following documents are required to be at the test site, before and during the performance of this procedure:

- WHC-IP-0842, Vol II Section 4.9.1, LOCKOUT/TAGOUT

- WHC-CM-1-10, WKS-8.1, OPERATIONS LOCK \& TAG PROGRAM

- WORK PACKAGE, ES-96-00589/M

4.3 The following conditions must be met before this test may commence:

4.3.1 A pre-job safety meeting has been held before performing this procedure in accordance with WHC-IP-0842, Vol $V$ Section 4.1, PRE-JOB SAFETY MEETING FORM.
Mond $l \mathrm{KL}$
$\frac{8 / 21 / 96}{\text { Date }}$

EXCEPTION \#1

4.3.2 Verify the equipment is fabricated and identified per ECN 632817 .

mel $8 / 2,196$

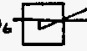

4.3.3 Verify all equipment is prepared for the test.

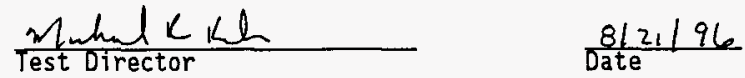

4.3.4 Verify test equipment is calibrated and record data on page 27.

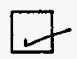

EXCEPTION \#6 COMPLETED by SIGNING below.

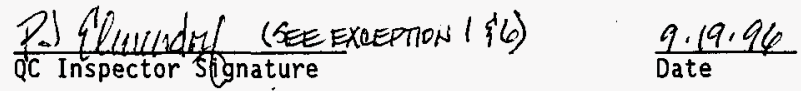

Rey/Mad

Revmod 


\section{TANK FAF. I PLANT OPERATIONS ?ROCEDURE}

\subsection{PROCEDURE}

\section{WARNING}

Energized circuits and leads are contained inside the equipment. Observe appropriate electrical precautions. Comply with WHC-CM-1-10, WKS-15, ELECTRICAL WORK SAFETY.

\subsection{MERCURY SWITCHES FUNCTIONAL TEST}

5.1.1 ENSURE that temporary power (120 VAC) is available to the Safety Class Shutdown System via a 15 amp circuit breaker and the breaker is open.

5.1.2 CONNECT 250 OHM resistor between terminals TB-3-1 and TB $-3-2$.

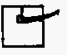

5.1.3 ENSURE temporary jumpers are installed on the FGM, DPM, and Ventilation System inputs.

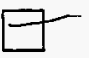

5.1.4 CONNECT temporary power to the SCSS and close the circuit breaker.

5.1.5 DEPRESS Seismic Reset Switch (PB-1).

5.1.6 VERIFY Power Available Indicator Light "ON".

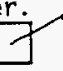

5.1.7 DEPRESS Pane] Reset switch (PB-2). Verify Trip Circuit Functional Indicator Light is "ON".

EXCEDTION \#2

5.1.8 RECORD voltage drop across Seismic Switch st. and the resistance across $\mathrm{K} 3-3$ (TB3-1,2).

4 mill: VAC .3 OHMS
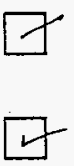
5.1 MERCURY SWITCHES FUNCTIONAL TEST (CONT.)

EXCEPTION \# 2

RESISTANCE

5.1.11 RECORD across Seismic Switch-SW-tiand the resistance across $\mathrm{K} 3-3$.

$\infty$ OHAC OHS

5.1.12 LOWER the cabinet to a level position.

ExCEPTION $\#$

EXCEPTION 2

ExCEPTION \# $\mathbf{2}$
5.1.13 REPEAT steps 5.1.5 through 5.1.12 five (5) times and record data below.

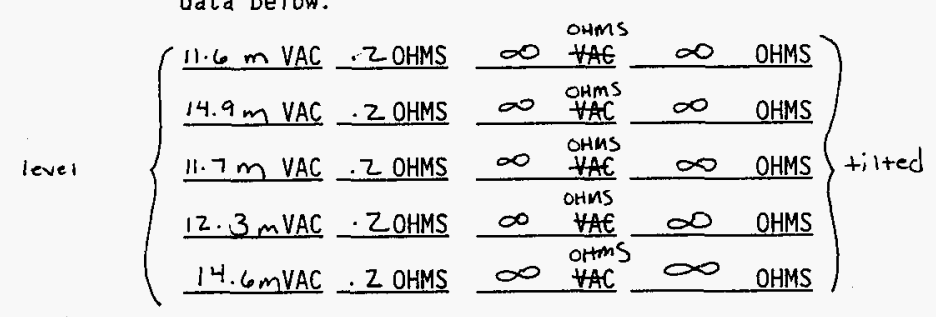

5.1.14 REPEAT steps 5.1.5 through 5.1.12 five (5) times and record data below. TILT cabinet 1-3 degrees in the opposite direction of the X-PIane.

\begin{tabular}{|c|c|c|c|c|c|}
\hline $2.9 \mathrm{~m} V \mathrm{VAC}$ & 2 OHMS & $\infty$ & $\forall A C$ & $\infty$ & OHMS \\
\hline $10.5 \mathrm{mVAC}$ & $20 \mathrm{HMS}$ & $\infty$ & $\begin{array}{l}\text { OHIMS } \\
\text { YAC }\end{array}$ & $\infty$ & OHMS \\
\hline $7.4 \mathrm{~m} \mathrm{VAC}$ & .20 & $\infty$ & $\begin{array}{l}\text { OHMS } \\
\text { YAE }\end{array}$ & $\infty$ & OHMS \\
\hline $6.5 \mathrm{~m}$ VAC & $20 \mathrm{HMS}$ & $\infty$ & $\begin{array}{l}\text { OHAS } \\
\text { YAC }\end{array}$ & $\infty$ & OHMS \\
\hline $7.1 \mathrm{~m} \mathrm{VAC}$ & $20 \mathrm{HMS}$ & $\infty$ & $\begin{array}{l}\text { OHMS } \\
\text { YAE }\end{array}$ & $\infty$ & $\mathrm{OHMS}$ \\
\hline
\end{tabular}

5.1.15 DEPRESS Seismic Reset Switch, AND PANEL RESET
MLK $8 / 22196$

5.1.16 ENSURE Power Avaitable Light is on.

5.1.17 RECORD the voltage drop across seismic switch SH-z and the resistance across $\mathrm{K3}-3$.

$3.8 \mathrm{mVAC}$

2 OHMS

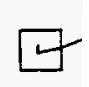




\subsection{MERCURY SWITCHES FUNCTIONAL TEST (CONT.)}

5.1.18 TILT cabinet $1-3$ degrees in the $Z-P 1$ ane

5.1.19 VERIFY Power Available Indicator Light and the Trip Circuit Function Indicator Light "OFF".

RESISTANCE
RECORD the altaga-drOP across seismic switch SW- $Z$ and the

EXCEPTION \#2

5.1 .20 resistance across $\mathrm{K} 3-3$.

Oo $\mathrm{ACOAMS}$ $2 \quad$ OHMS

5.1.21 LOWER the cabinet to a level position.

EXCEPTION $\# 2$

5.1.22 REPEAT steps 5.1.15 through 5.1.21 five (5) times and record data below.

$10.9 \mathrm{~m}$ VAC $2 \mathrm{ZOHMS}$

$11.0 \mathrm{mVAC} .2$ OHMS

$8.4 \mathrm{~m} V A C .2$ OHMS

$10.4 \mathrm{mVAC} .2$ OHMS

$10.9 \mathrm{mVAC} .2 \mathrm{OHMS}$

\begin{tabular}{|c|c|c|c|}
\hline$\infty$ & $\begin{array}{l}\text { OHMS } \\
\forall A C\end{array}$ & $\infty$ & OHMS \\
\hline$\infty$ & $\begin{array}{l}\text { orms } \\
\text { VAC }\end{array}$ & $\infty$ & $\mathrm{OHMS}$ \\
\hline$\infty$ & $\begin{array}{l}\text { Orims } \\
\text { YAG }\end{array}$ & $\infty$ & OHMS \\
\hline$\infty$ & $\begin{array}{l}\text { cHims } \\
\text { YAC }\end{array}$ & $\infty$ & OHMS \\
\hline$\infty$ & $\begin{array}{l}O H M S \\
H A E\end{array}$ & $\infty$ & OHMS \\
\hline
\end{tabular}

EXCEPTION 72

5.1.23 REPEAT steps 5.1.15 through 5.1.21 five (5) times and record data below. TILT cabinet in the opposite direction in the ZPlane.

\begin{tabular}{|c|c|c|c|c|c|}
\hline $\begin{array}{l}\text { Plane. } \\
14.6 \mathrm{~m} \text { VAC }\end{array}$ & $.3 \mathrm{OHMS}_{\mathrm{HAC}}^{\mathrm{Hat}}$ & $\infty$ & OHMS & $\infty$ & OHMS \\
\hline $8.8 \mathrm{mVAC}$ & $.2 \stackrel{\text { OHMS }}{\text { YAC }}$ & $\infty$ & OHMS & $\infty$ & OHMS \\
\hline $8.2 \mathrm{mV}$ & $.3 \stackrel{\text { onims }}{\forall A C}$ & $\infty$ & OHMS & $\infty$ & $\mathrm{OHMS}$ \\
\hline $6.0 \mathrm{~m} \mathrm{VAC}$ & $.3 \stackrel{\text { Otms }}{\text { VAE }}$ & $\infty$ & OHMS & $\infty$ & OHMS \\
\hline 7. $2 \mathrm{mV}$ & $.2^{\mathrm{OHMS}}$ & $\infty$ & $\mathrm{OH}$ & $\infty$ & $\mathrm{OH}$ \\
\hline
\end{tabular}

7. $2 \mathrm{mVAC}-2 \mathrm{VAC}+\infty$ OHMS 


\subsection{MERCURY SWITCHES FUNCTIONAL TEST (CONT.)}

5.1.24 OPEN temporary power circuit breaker.

5.1.25 Test Director SHALL VERIFY that section 5.3 is COMPLETE by SIGNING belOW.

$$
\frac{\text { Mhal } R \text { Kh }}{\text { Test Director Signature }} \quad \frac{8 / 21 / 96}{\text { Date }}
$$

5.1.26 QC Inspector SHALL VERIFY that section 5.3 is COMPLETE

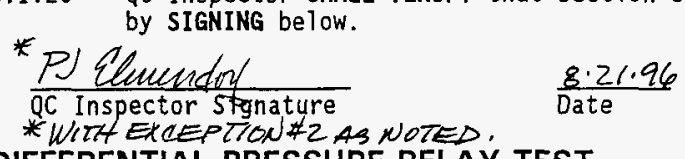

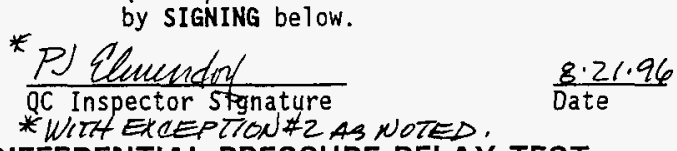

5.2 DIFFERENTIAL PRESSURE RELAY TEST

5.2.1 ENSURE cabinet is de-energized.

5.2.2 REMOVE DPM temporary input jumper.

$$
-1(+)
$$

EXCEPTION 3

5.2.3 CONNECT 4-20 ma current source to TB-3-4(+) and $\mathrm{TB}-3-5(-)$ in cabinet A (SALW-PNL-O8OH).

$$
-\mathbf{z}(-)
$$

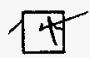

5.2.4 CONNECT 250 OHM resistor between terminals TB-3-4 and TB-3-z in cabinet $A$. (if not already connected).

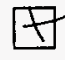

EXCEDTION $\$ 4$
EXCEPTION $\# 5$

5.2.5 CLOSE temporary power circuit breaker.

5.2.6 DEPRESS Seismic Reset Switch (PB-1). VERIFY Power Available Light "ON".

5.2.7 RESET DPM alarm module by Pecreasing source until the module resets. Verify by measuring voltage drop across DPM alarm contacts.

5.2.8 DEPRESS Pane? Reset Pushbutton (PB-2). "VERIFY" Trip Circuit Functional Indicating Light "ON".

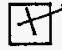
$-4$

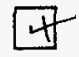




\subsection{DIFFERENTIAL PRESSURE RELAY TEST (CONT.)}
EXCEPTION 5

\section{2 .9}
5.2 .10
JNCREASINES
TRIP DPM alarm module by JNCREASING until the module trips.
VERIFY Trip Circuit Functional Indicating Light is OFF.

EXCEPTION $\# 3$

5.2.11 OPEN temporary power circuit breaker. $-1(+)$

5.2.12 REMOVE 4-20 ma current source from $\mathrm{TB}-3-4++$ and
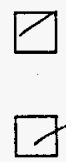
$\begin{aligned} T B-3-5(\rightarrow) & \text {. } \\ -2(-) & .\end{aligned}$

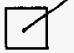

5.2.13 INSTALL DPM temporary input jumper.

5.2.14 Test Director SHALL VERIFY that section 5.2 is COMPLETE by SIGNING below.
$\frac{\text { Malnch }}{\text { Test Director Signature }}$
$\frac{8 / 22 / 86}{\text { Date }}$

5.2.15 QC Inspector SHALL VERIFY that section 5.2 is COMPLETE by SIGNING below.
P) Qlousucdol
$\mathrm{QC}$ Inspector Signature

\section{$\frac{8 \cdot 22 \cdot 86}{\text { Date }}$}

WITLEXCEPTIONS H3,4, 95 AS NOTED.

\subsection{FLAMMABLE GAS MONITOR INPUT SIGNAL FUNCTIONAL}

TEST

5.3.1 ENSURE cabinet is de-energized.

5.3.2 REMOVE temporary jumper from the FGM system input.

5.3.3 CONNECT temporary light switch across input terminals of FGM system input. CLOSE light switch.

5.3.4 CLOSE temporary power circuit breaker. 


\subsection{FLAMMABLE GAS MONITOR INPUT SIGNAL FUNCTIONAL TEST (CONT.)}

5.3.5 VERIFY Power Available 7 ight and Trip Circuit Functional Indicator Light are "OFF".

5.3.6 DEPRESS Seismic Reset Switch (PB-1). VERIFY Power Available Light "ON".

5.3.7 DEPRESS Panel Reset Pushbutton (PB-2). "VERIFY" Trip Circuit Functional Indicating Light "ON".

5.3.8 CONNECr voltmeter across relay contact K1-1 (TB12, TB2-2). MEASURE and record voltage.

$4.2 m \quad V A C$

5.3.9 OPEN temporary light switch. VERIFY Trip Circuit Functional Indicating Light is OFF.

5.3 .9 .

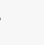

5.3.10 MEASURE and RECORD voltage drop across relay contact Kl-1.

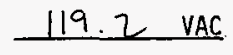

5.3.11 CLOSE temporary light switch.

5.3.12 DEPRESS Panel Reset Pushbutton (PB-2). "VERIFY" Trip Circuit Functional Indicating Light "ON".

5.3.13 CONNECT voltmeter across relay contact K1-2 (TB12, TB2-3). 


\subsection{FLAMMABLE GAS MONITOR INPUT SIGNAL FUNCTIONAL TEST (CONT.)}

5.3.14 MEASURE and RECORD voltage drop across relay contact KI-2.

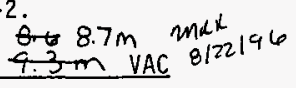

5.3.15 OPEN temporary light switch. VERIFY Trip Circuit Functional Indicating Light is OFF.

5.3.16 MEASURE and RECORD voltage drop across relay contact $\mathrm{K} 1-2$.

119.2 VAC

5.3.17 CLOSE temporary iight switch.

5.3.18 DEPRESS Panel Reset Pushbutton (PB-2). "VERIFY" Trip Circuit Functional Indicating Light "ON".

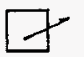

5.3.19 CONNECT voltmeter across relay contact K2-I (TB1ok 2, TB2- 2 Channel B).

$$
\text { mil } 8 / 22 / 96
$$

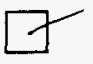

5.3.20 MEASURE and RECORD voltage drop across relay contact

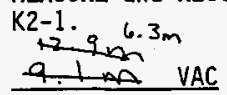

5.3.21 OPEN temporary light switch. VERIFY Trip Circuit Functional Indicating Light is OFF.

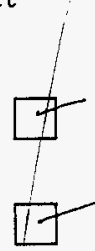




\subsection{FLAMMABLE GAS MONITOR INPUT SIGNAL FUNCTIONAL TEST (CONT.)}

5.3.22 MEASURE and RECORD voltage drop across relay contact K2-1.

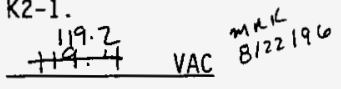

5.3.23 CLOSE temporary light switch.

5.3.24 DEPRESS Panel Reset Pushbutton (PB-2). "VERIFY" Trip Circuit Functional Indicating Light "ON".

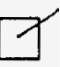

5.3.25 CONNECT voltmeter across relay contact K2-2 (TBI2, TB2-3 Channel B).

5.3 .26

MEASURE and RECORD voltage drop across relay contact $\mathrm{K} 2-2$.

$8.3 \mathrm{~m} V \mathrm{VAC}$

5.3.27 OPEN temporary light switch. VERIFY Trip Circuit Functional Indicating Light is OFF.

5.3.28 MEASURE and RECORD voltage drop across relay contact $\mathrm{K} 2-2$.

$119.3 \quad$ VAC

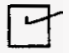

5.3.29 OPEN temporary power circuit breaker.

5.3.30 REMOVE temporary light switch.

5.3.31 INSTALL the temporary FGM system input jumper.
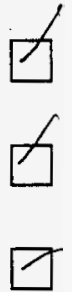


\section{TANK FAKIV PLANT OPERATIONS PROCEDURE}

\subsection{FLAMMABLE GAS MONITOR INPUT SIGNAL FUNCTIONAL TEST (CONT.)}

5.3.32 Test Director SHALL VERIFY that section 5.3 is COMPLETE bY SIGNING below.

$$
\frac{\text { Mhl ith }}{\text { Test Director Signature }} \frac{8 / 21 / 96}{\text { Date }}
$$

5.3.33 QC Inspector SHALL VERIFY that section 5.3 is COMPLETE by SIGNING below.

$$
\frac{\text { PJ Eluundol }}{\text { QC Inspector Signature }} \frac{8.21 \cdot 96}{\text { Date }}
$$

\subsection{VENTILATION SKID FLOW INPUT SIGNAL FUNCTIONAL TEST}

5.4.1 ENSURE cabinet is de-energized.

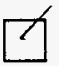

5.4.2 REMOVE the temporary jumper across the Ventilation Skid Flow Input.

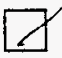

5.4.3 INSTALL temporary light switch across input terminals of Ventilation system input.

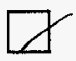

5.4.4 CLOSE the temporary power circuit breaker.

5.4.5 VERIFY Power Available light and Trip Circuit

Functional Indicator Light are "OFF".

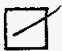

5.4.6 DEPRESS the PB-1. VERIFY Power Available Light is ON. 


\subsection{VENTILATION SKID FLOW INPUT SIGNAL FUNCTIONAL TEST (CONT.)}

5.4.7 DEPRESS Panel Reset Pushbutton (PB-2). "VERIFY" Trip Circuit Functional Indicating Light "ON".

5.4.8 OPEN the temporary light switch.

5.4.9 VERIFY Trip Circuit Functional Indicating Light is OFF.

5.4.10 OPEN the temporary power circuit breaker.

5.4.11 REMOVE the temporary light switch.

5.4.12 INSTALL temporary jumper across the Ventilation Skid flow Input.

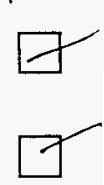


5.5.2 REMOVE the temporary jumper across FGM input.

5.5.3 INSTALL temporary light switch across FGM System input.

\section{EXCEPTION \#6 6.5 .4}

INSTALL an event recorder with the following inputs:

CH1 -- FGM Input

CH2 -- PMP-1-1

CH3 -- PMP-2-1

5.5.5 INSTALL ohmmeter across auxiliary contacts PMP-1-2 and PMP-2-2 (Channel A TB2-7,8).

5.5.10 RESET event recorder.

5.5.11 RECORD resistance across auxiliary contacts PMP-1-2 and PMP-2-2.

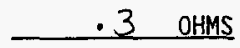

5.5.12 OPEN the temporary light switch.
5.5.6 CLOSE the temporary power circuit breaker.

5.5.7 VERIFY Power Available light and Trip Circuit Functional Indicator Light are "OFF".

5.5.8 DEPRESS Seismic Reset Switch (PB-1). VERIFY Power Available Light "ON".

5.5.9 DEPRESS Panel Reset Pushbutton (PB-2). "VERIFY" Trip Circuit Functional Indicating Light "ON".
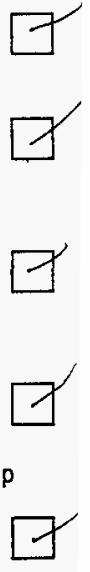


\subsection{CONTACTORS FUNCTIONAL TEST AND SHUTDOWN SYSTEM TIME RESPONSE (CONT.)}

5.5.13 VERIFY Panel Trip Functional Indicating Light is OFF.

5.5.14 RECORD elapsed time from input trip to contactor operation. (This time should be less than. 1 second.) $10 \mathrm{msec}$ (record longest time response)

5.5.15 RECORD resistance across auxiliary contacts PMP-1-2

$\infty \quad$ OHMS

\section{and PMP-2-2.}

$\infty$ OHMS

5.5.16 CLOSE the temporary light switch.

5.5.17 REPEAT steps 5.5.8 through 5.5.16 four times and

record resistance and time response below.

.3 OHMS $>10 \mathrm{msec} \infty$ OHMS

\begin{tabular}{|c|c|c|c|}
\hline .3 OHMS & 10 & msec & $\infty$ OHMS \\
\hline .3 OHMS & 10 & msec & $\infty$ OHMS \\
\hline . 3 OHMS & 10 & msec & $\infty$ OHMS \\
\hline
\end{tabular}

5.5.18 CONNECT ohmmeters across contactors HT1-1, HT1-2, PMP1-1, and PMP1-2.

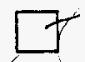




\title{
TANK FAhıV PLANT OPERATIONऽ PROCEDURE
}

\subsection{CONTACTORS FUNCTIONAL TEST AND SHUTDOWN SYSTEM TIME RESPONSE (CONT.)}

5.5.20 DEPRESS Panel Reset Pushbutton (PB-2). "VERIFY" Trip Circuit Functional Indicating Light "ON".

5.5.21 RECORD the resistance indicated by the ohmmeters in DATA SHEET I.

5.5.22 OPEN the temporary light switch. VERIFY Trip Circuit Function Light is OFF. RECORD the resistance indicated by the ohmmeters DATA SHEET I. (Ohmmeters should indicate an open circuit)

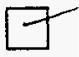

5.5.23 REPEAT steps 5.5.19 through 5.5.22 twenty five (25) times.

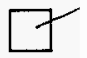

5.5.24 REMOVE the ohmmeters.

5.5.25 OPEN temporary power circuit breaker.

5.5.26 REMOVE temporary Tight switch.

5.5.27 INSTALL the temporary jumper removed in step $\mathbf{5 . 5 . 2}$

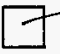

(5.

\begin{abstract}
REMOve temporary light switch.
\end{abstract}

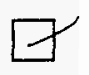

5.5.28 Test Director SHALL VERIFY that section 5.5 is COMPLETE bY SIGNING belOW.
$\frac{\text { Mhl } k \text { L } L \text { Dignature }}{\text { Test Director Signa }}$
$\frac{8 / 22 / 96}{\text { Date }}$ 


\subsection{CONTACTORS FUNCTIONAL TEST AND SHUTDOWN SYSTEM TIME RESPONSE (CONT.)}

5.5.29 QC Inspector SHALL VERIFY that section 5.5 is COMPLETE by SIGNING below.

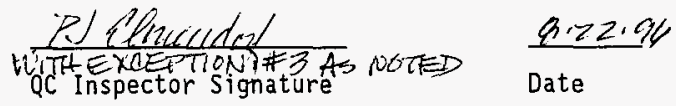

\subsection{CONTROL CABINET A FUNCTIONAL TEST}

5.6.1 ENSURE temporary jumpers are installed on the system inputs.

5.6.2 CLOSE the temporary power circuit breaker.

5.6.3 DEPRESS Seismic Reset Switch (PB-1). VERIFY Power Available Light "ON".

5.6.4 DEPRESS Panel Reset Pushbutton (PB-2). "VERIFY" Trip Circuit Functional Indicating Light "ON".

5.6.5 DEPRESS the manual shutdown pushbutton switch (PB-3).

5.6.6 ENSURE and RECORD Trip Circuit Functional Indicator Light is off.

ON

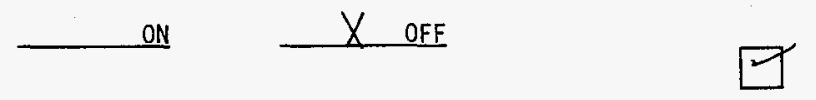




\subsection{CONTROL CABINET A FUNCTION TEST (CONT.)}

5.6.7 REPEAT steps 5.6.4 through 5.6.6 ten (10) times.

\begin{tabular}{|c|c|c|}
\hline ON & $x$ & OFF \\
\hline ON & $x$ & OFF \\
\hline ON & $x$ & OFF \\
\hline ON & $x$ & OFF \\
\hline ON & $x$ & OFF \\
\hline ON & $x$ & OFF \\
\hline$O N$ & $x$ & OFF \\
\hline ON & $x$ & OFF \\
\hline ON & $x$ & OFF \\
\hline ON & $x$ & OFF \\
\hline
\end{tabular}

5.6.8 OPEN temporary power circuit breaker.

5.6.9 REMOVE temporary jumpers.

5.6.10 Test Director SHALL VERIFY that section 5.6 is COMPLETE by SIGNING below.

$\frac{M / h d K K l}{\text { Test Director Signature }} \quad \frac{8 / 22 / 46}{\text { Date }}$

5.6.11 QC Inspector SHALL VERIFY that section 5.6 is COMPLETE by SIGNING below.

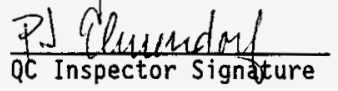

$\frac{8.22 \cdot 96}{\text { Date }}$ 


\section{TANK FAnM PLANT OPERATIONu PROCEDURE}

IEST EQUIPMENT CALIBRATION DATA

INSTRUMENT NUMBER

MULTI.METER

TRANSMATION

MULTI-METER
(C) PIE $\$ .21 .64$

$681 \cdot 45-80 \cdot 002$

$681-13-20-\infty 1$

$681-45 \cdot 08001$
CALIBRATION DATE

$12 / 12195$

$60+1212+96$

$10 / 26 / 95$

$10 / 25 / 95$
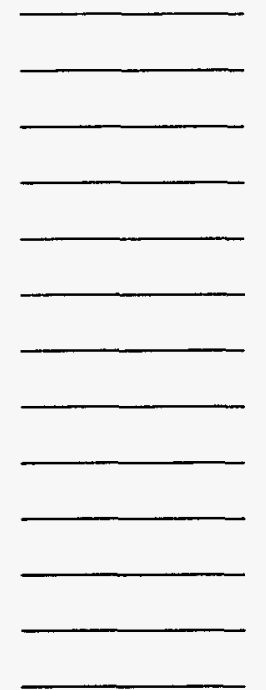

EXPIRATION DATE $12 / 12 / 96$ $10 / 26 / 96$ $10 / 26 / 96$ 


\section{TANK FARM PLANT OPERATIONS PROCEDURE}

FIGURE 5.1 SAFETY CLASS CONTROL CABINET A EXCEPTION \# 7

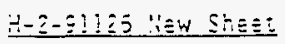

Dorre Fiess

Isolator

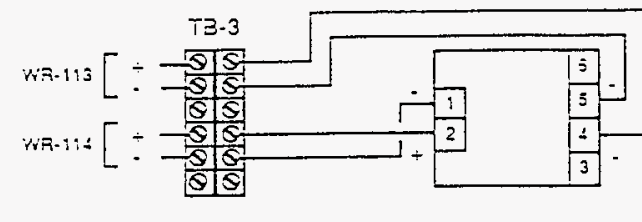

Dome Prass

Alarm Miccule

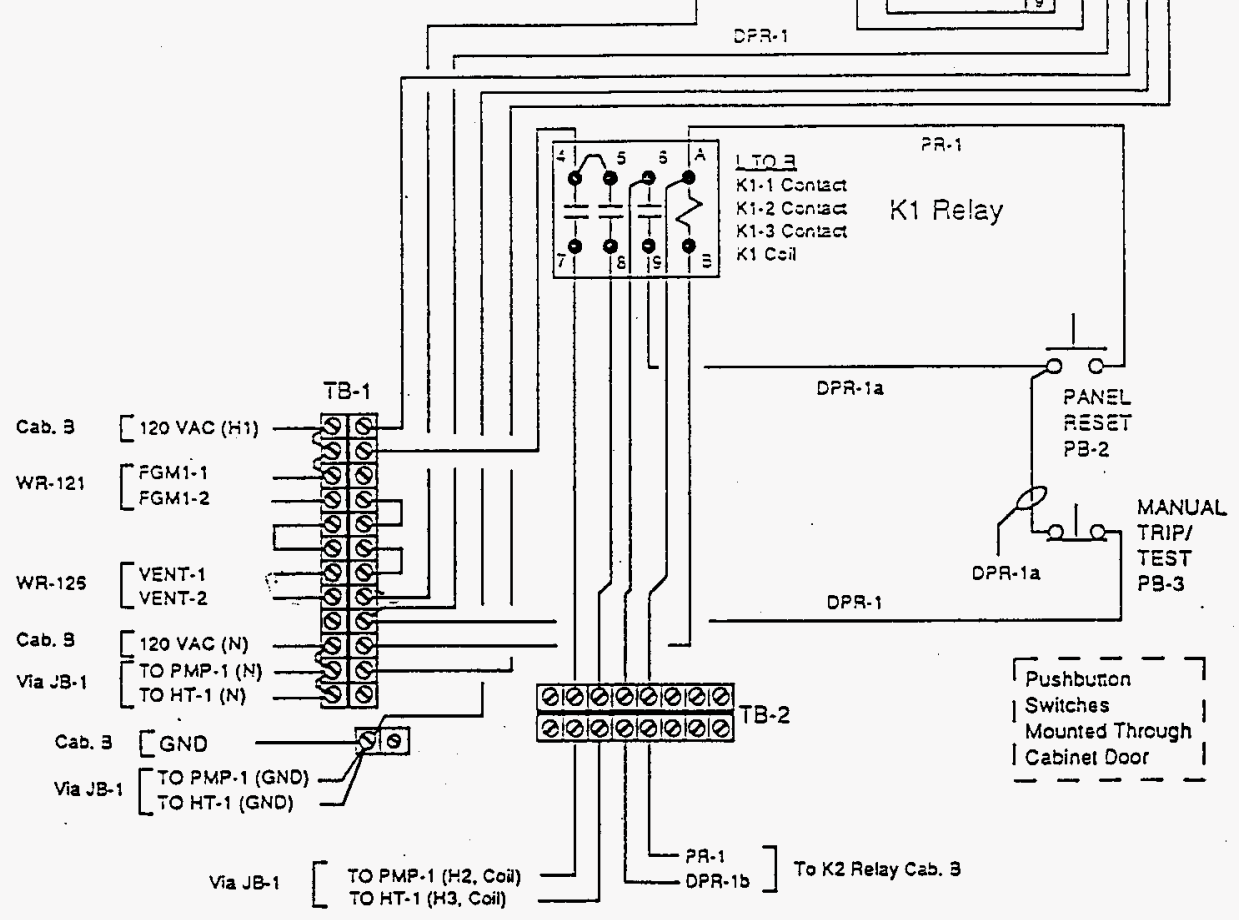

\section{Safety Class Control Cabinet (A) (SALW-PNL-808H)}




\section{TANK FARM PLANT OPERATIONS PROCEDURE}

\section{FIGURE 5.2 SAFETY CLASS CONTROL CABINET B EXCETTION \# 7}

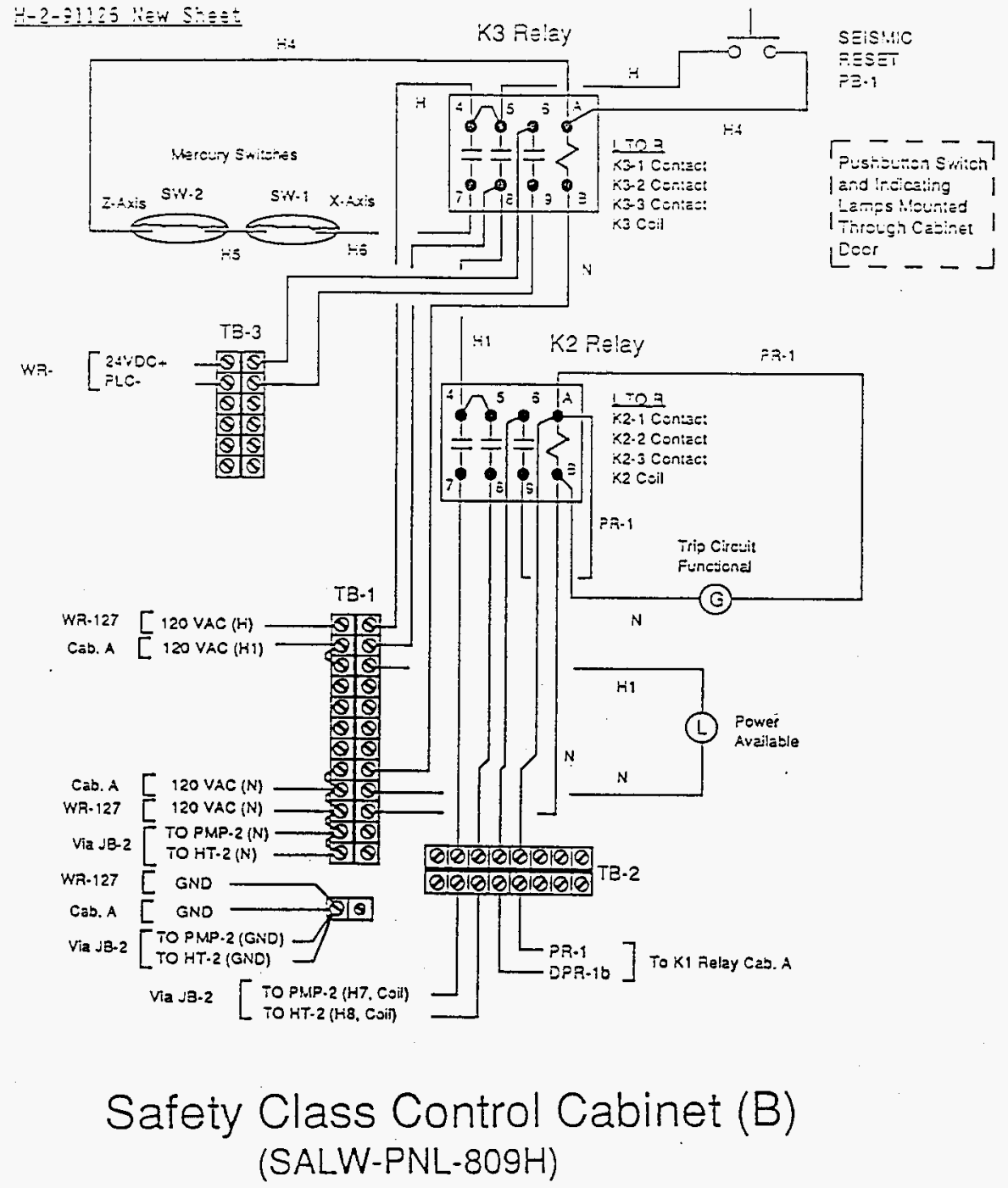

\begin{tabular}{|l|ll|l|}
\hline Document No. & Rev/Mod & Page \\
WHC-SD-WM-ATR-185 & & 0 & A-29 \\
\hline
\end{tabular}




\section{DATA SHEET LOG}

This page may be reproduced as necessary PAGE 1 of 1

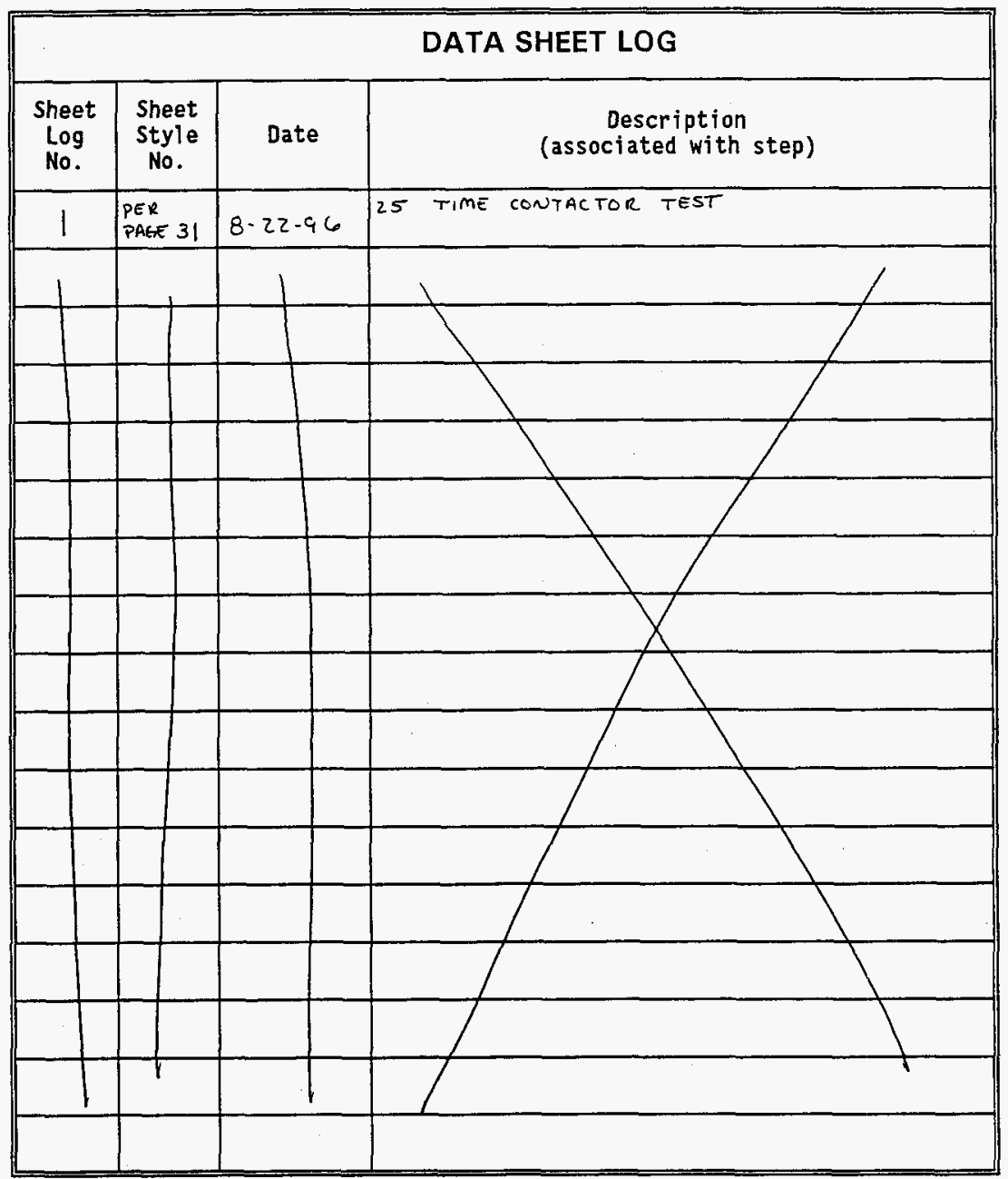




\section{TANK FARM PLANT OPERATIONS PROCEDURE}

\section{DATA SHEET I}

This page may be reproduced as necessary

Page 1 of 1

These readings taken as a part of Section 5 of this ATP.

g Time readings taken 11:00 Date $8 / 22 / 96$

$8|8|$

$8|g|$

STEP 5.5.21 (OHMS)

STEP 5.5.22 (OHMS)

8181

81

11-1 HT1-2 PMP1-1 PMPI-2

HT1-1 HT1-2 PMP1-1 PMP2-1

$m$

2) $\frac{.4 \Omega}{1.0 \Omega} \frac{1.2 \Omega}{.2 \Omega} \frac{.3 \Omega}{.6 \Omega} \frac{.4 \Omega}{.2 \Omega}$

丁.

h. 3). .5 . $3 \Omega .3 \Omega .78 \Omega$

N.)

$\sigma: 1$

4) . $3 \Omega$

$.2 \mu$

니시

$.3 \wedge$

r. $m !$

5). $.3 \Omega .2 \Omega .4 \Omega .6 \Omega$

m 91

6) $2.3 \Omega .2 \Omega .5 \Omega .4 \Omega$

7) .76 . $2 \Omega \quad .5 \quad .3$

In

8) .3

$\div 2 \div 6$

.4

9) .3

.2

.4 .43

10) 3

1.3

2.1

. 2

8181

11) .4

.2

.6

$\cdot 3$

12)

$.9-1.5$

.2

$8|8|$

8

13) .4

.4

1.5

$\cdot 2$

14) .6

.2 .6 .2

15) .5

$1.6 \quad .3$

2

16) $.4 .2 \quad 3.9 .2$

$m$

h

17) 1.7 .7 .4

9.1

is

18) 1.0

1.2 .6 .2

19) .9

.3

$3 \cdot 1$

$\frac{.2}{2.7}$

20) $\frac{1.6}{1.0}$

$\frac{.3}{.4} \frac{.3}{4.8} \frac{.7}{4}$

$\infty \frac{\infty}{\infty}-\infty$

$\infty \infty \infty$

$\infty \infty \infty$

$\infty \quad \infty$

$\infty \infty$

$\infty-\infty$

$\infty \quad \infty$

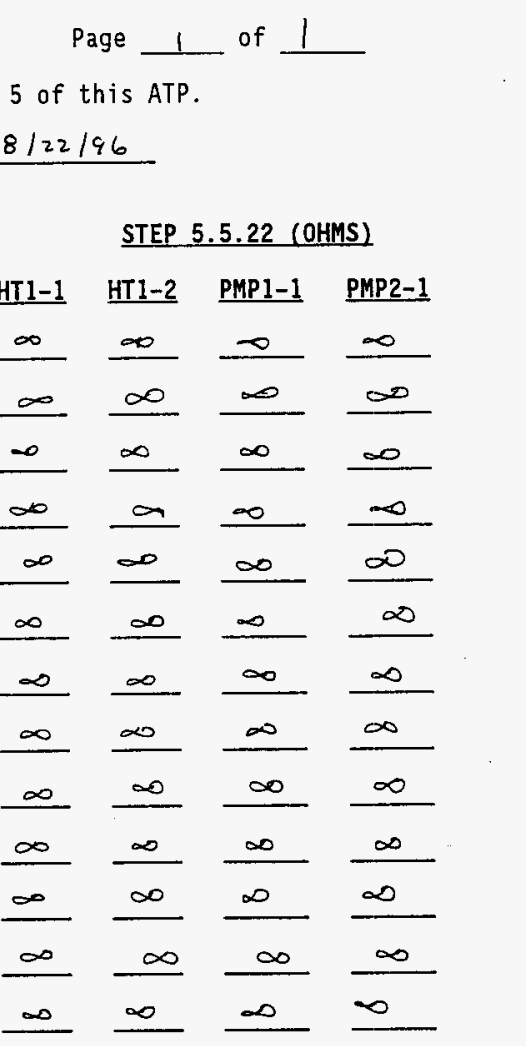

$\infty$

ग

ง.

N

WHC-SD-WM-ATR- 185
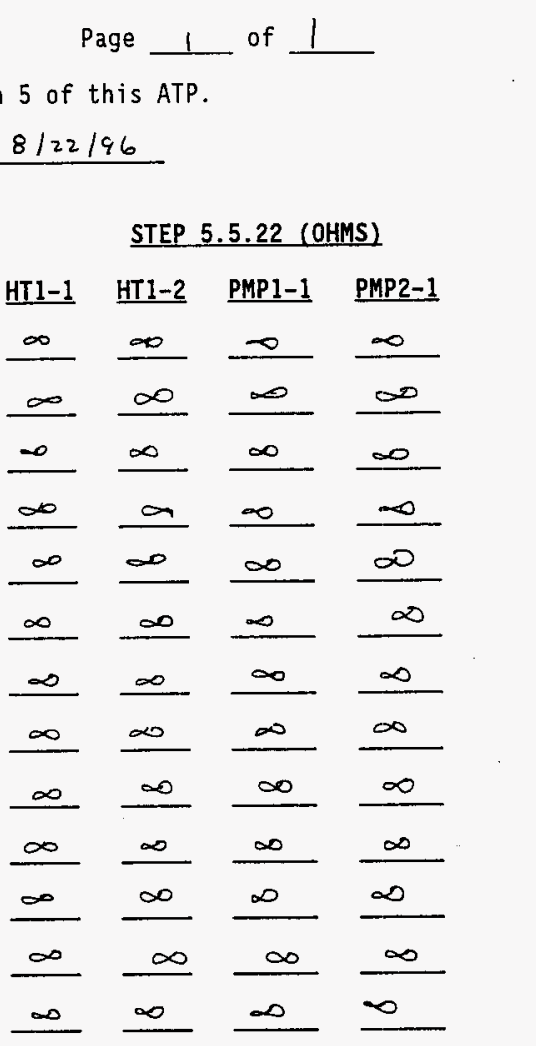

$\infty$

$\infty$

$\infty$

$\rightarrow$

$\infty$

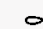

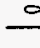

$\infty$

$-\infty \quad+\infty$

$\infty$

$\infty \quad \infty$

$\infty$

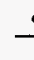

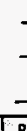

R
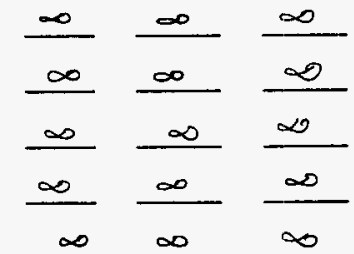

WHC-SD-WM-ATR-185 


\section{ATP EXCEPTION LOG}

This page may be reproduced as necessary PAGE

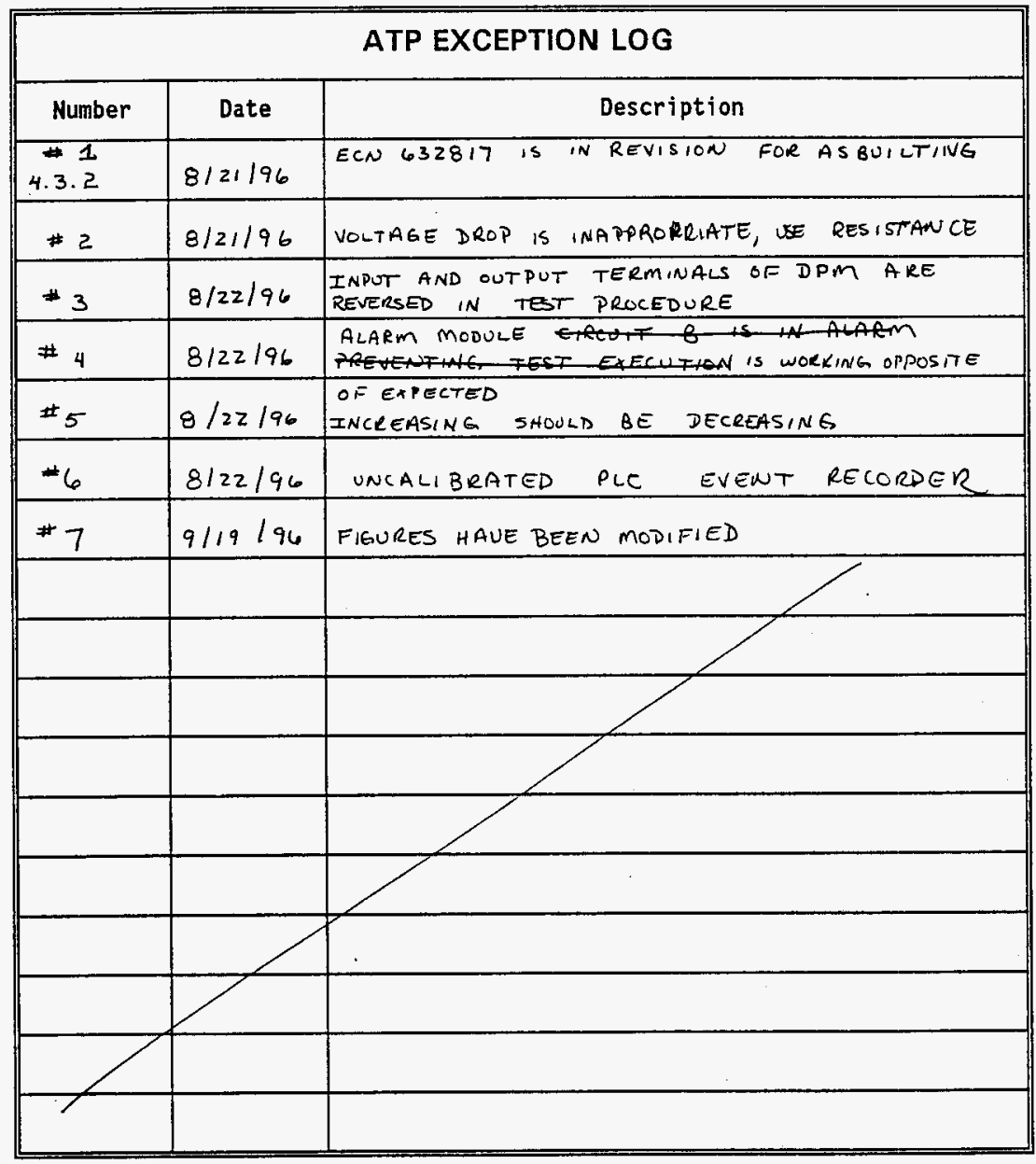




\section{ATP EXCEPTION RECORD}

This page may be reproduced as necessary.

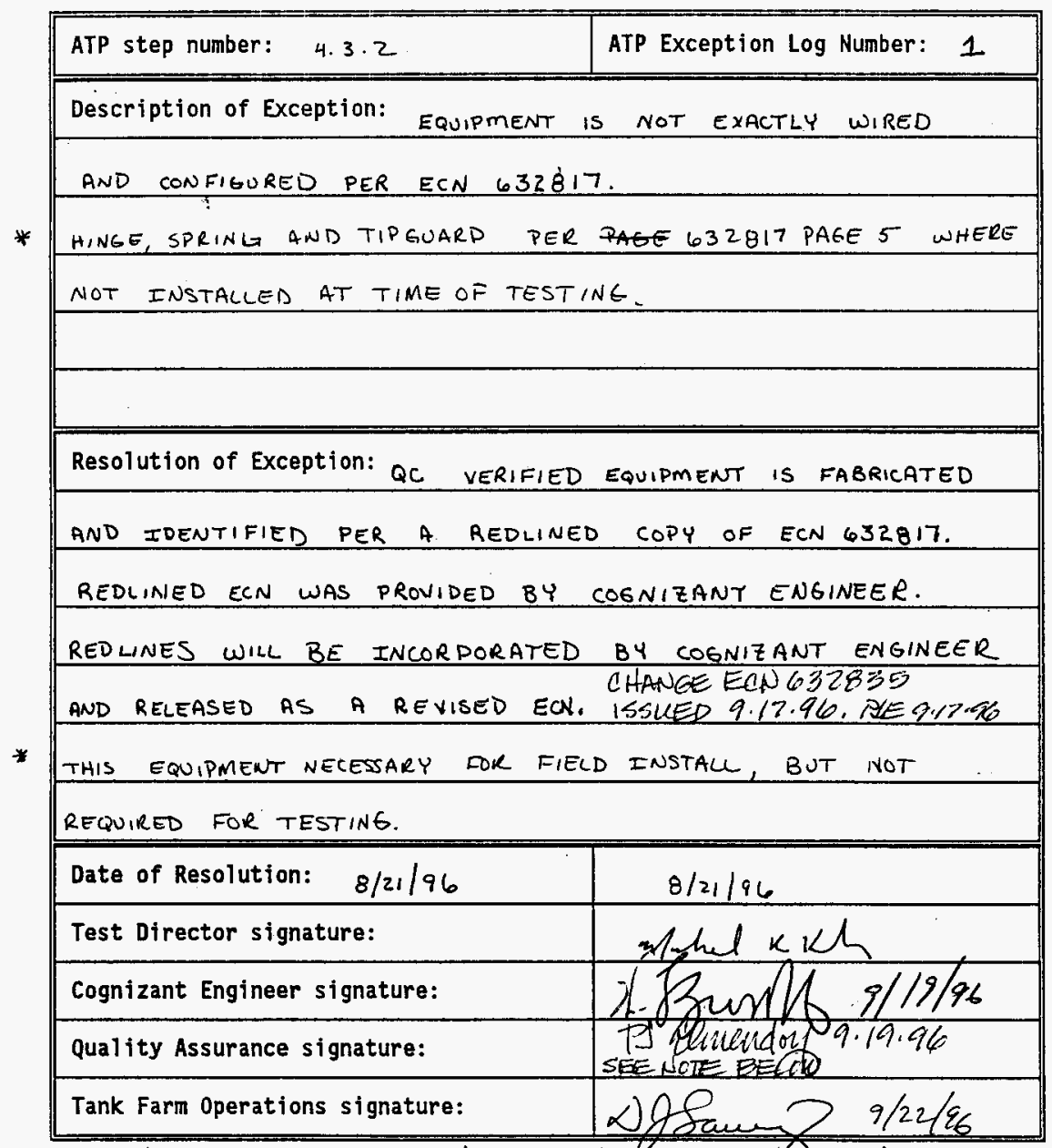

QC VERIFATION PER STEP 4.3.2 WAS LIMITES TO SHOP WORK; HO FIELD IVIRING YET INSTALLED. CHANEES MADE BU EUN 632835 DO NOT RERRESENT CHANEES W CONFIGURATICN THAT ULULD AFFED ATP RESULTS (EXCEPT AS SPECIFIED IN CTELE EXCEPTIONS TO TH(LS TEST). TEEY REPRESENT

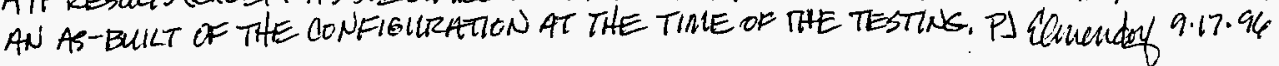




\section{ATP EXCEPTION RECORD}

This page may be reproduced as necessary.

\begin{tabular}{|c|c|}
\hline ATP step number: $\begin{array}{l}5.1 .8,5.1 .20,5.1 .22,5.1 .23 \\
5.1 .11,5.1 .13,5.1 .14,5.1 .17\end{array}$ & ATP Exception Log Number: $Z$ \\
\hline \multicolumn{2}{|l|}{ Description of Exception: YOLTAGE } \\
\hline \multicolumn{2}{|c|}{ MEANING FUL WHEN CIRCUIT IS DEËNERGIZED. ALSO, IT IS IMPRACTICAL } \\
\hline \multicolumn{2}{|c|}{ TO MEASURE ACROSS inDINIDUAL MERCURY SWITCHES AS 2 QRE IN THE " $x$ " } \\
\hline \multicolumn{2}{|c|}{ PLANE AND 2 ARE IN THE" $Z^{\prime \prime}$ PLANE, ALL WIRED IN SERIES WITH } \\
\hline \multicolumn{2}{|l|}{ NO TERMINAL ACCESS } \\
\hline \multicolumn{2}{|c|}{ Resolution of Exception: MEASURE RESISTANCE ACRCSS ENTIRE } \\
\hline \multicolumn{2}{|c|}{ SERIES OF MERCURY SWITCHES. VISUALLY VERIFY } \\
\hline \multicolumn{2}{|c|}{ THE CORRECT ( $X$ PLANE OR $Z$ PLANE) MERCURY SWITHH. IS } \\
\hline \multicolumn{2}{|l|}{ ACTUATED. } \\
\hline GLASS TUBE STYLE MERCURY SWITCHES & ARE EASILY \\
\hline \multicolumn{2}{|l|}{ OPEN OR CLOSED. } \\
\hline \multicolumn{2}{|c|}{\begin{tabular}{l|l} 
Date of Resolution: $8 / 21 / 96$ & $8 / 21 / 96$ \\
\end{tabular}} \\
\hline \multicolumn{2}{|l|}{ Test Director signature: } \\
\hline \multicolumn{2}{|l|}{ Cognizant Engineer signature: } \\
\hline Quality Assurance signature: & ivividat 9.19 .96 \\
\hline Tank Farm Oper & $2 / 86$ \\
\hline
\end{tabular}




\section{ATP EXCEPTION RECORD}

This page may be reproduced as necessary.

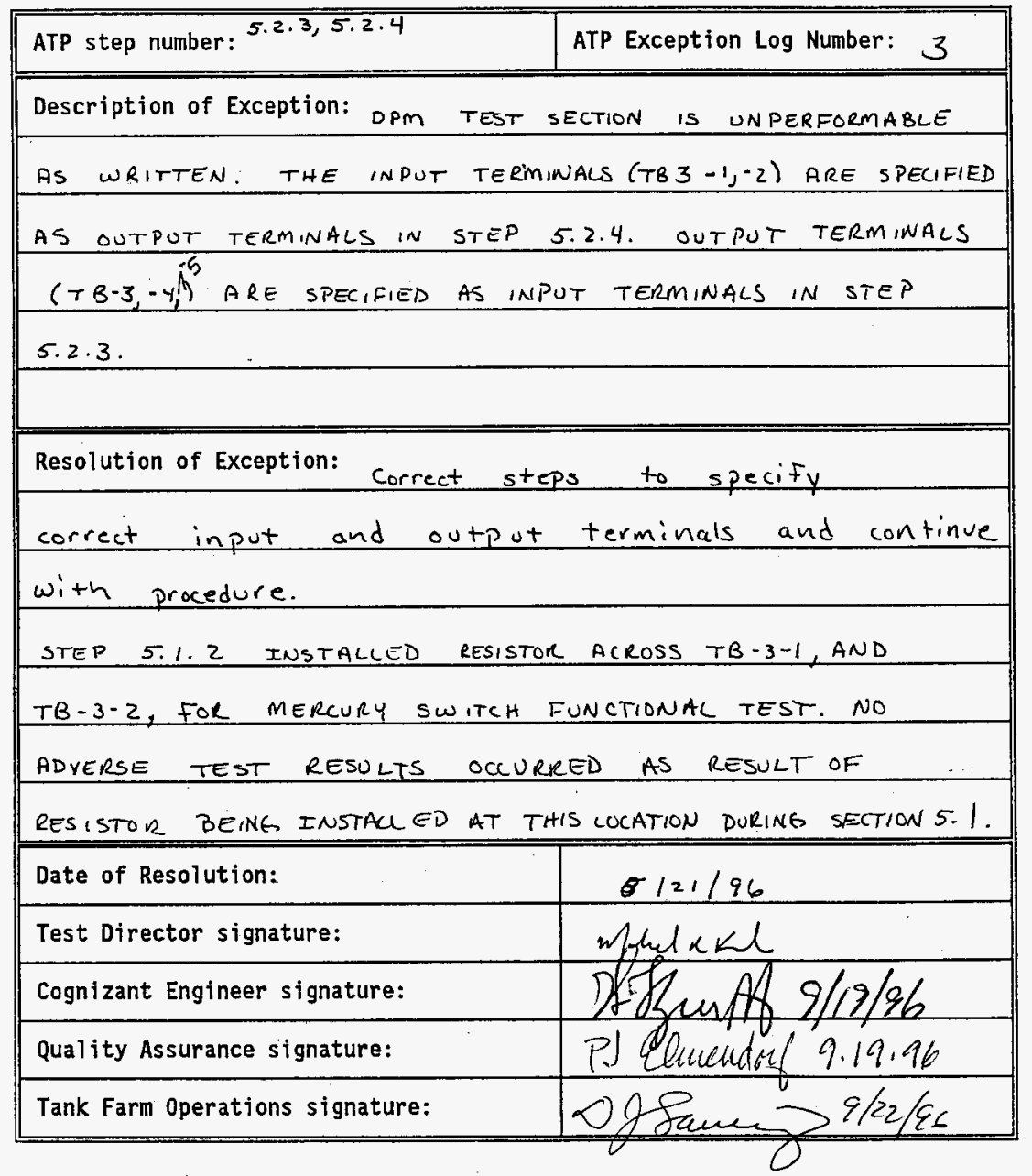




\section{ATP EXCEPTION RECORD}

This page may be reproduced as necessary.

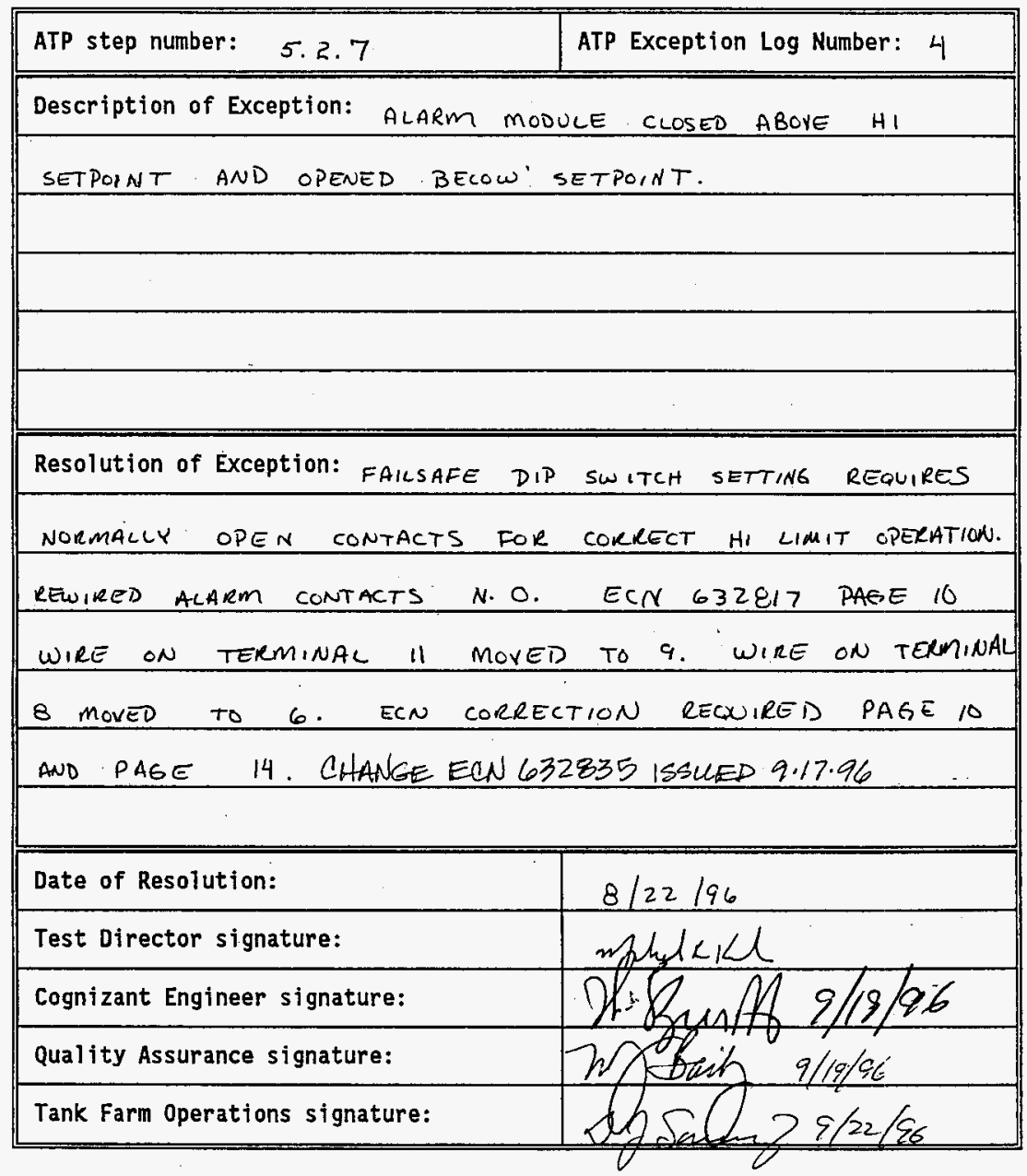




\section{ATP EXCEPTION RECORD}

This page may be reproduced as necessary.

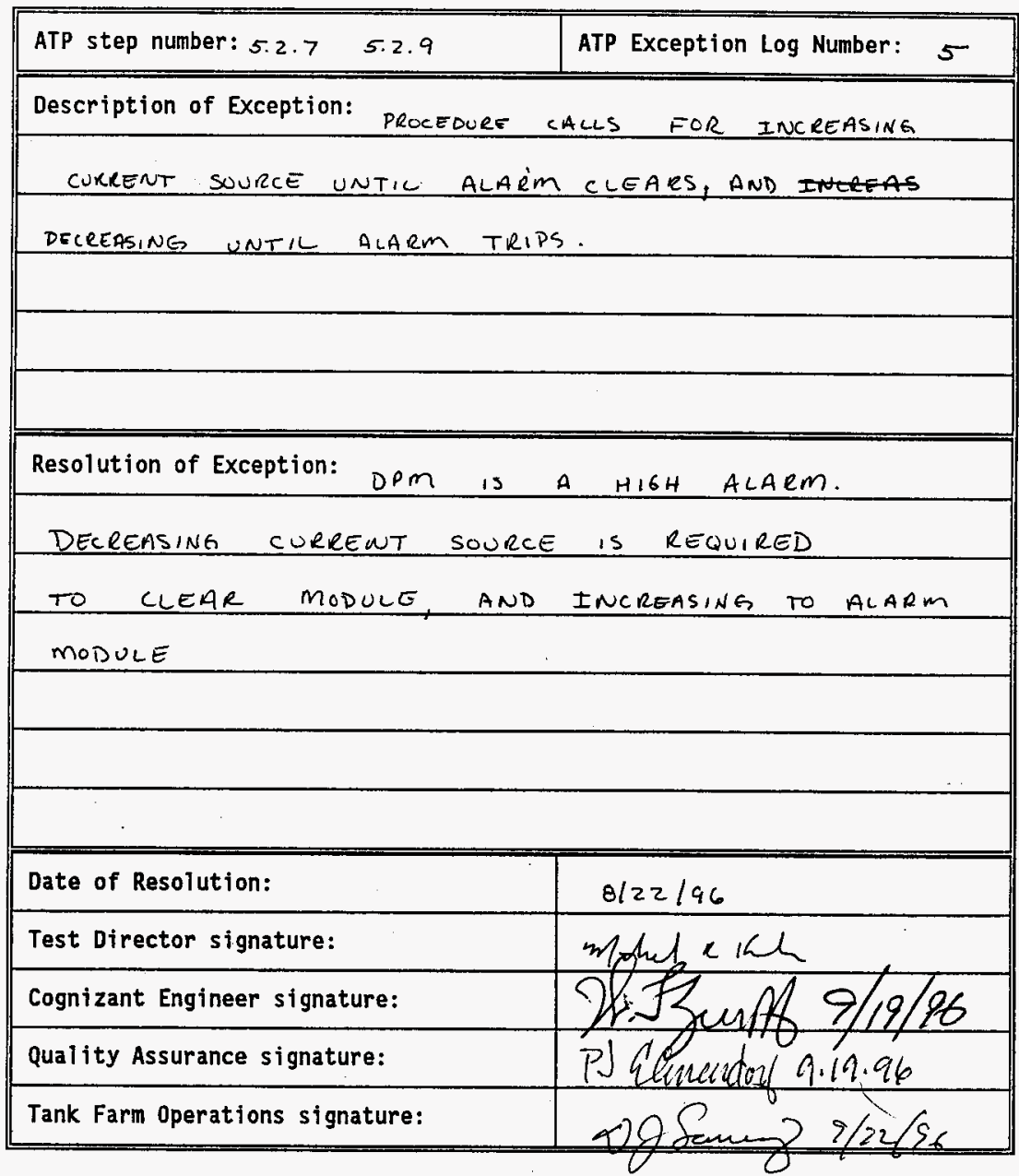




\section{TANK FAR'M PLANT OPERATIONS PROCEDURE}

\section{ATP EXCEPTION RECORD}

This page may be reproduced as necessary.

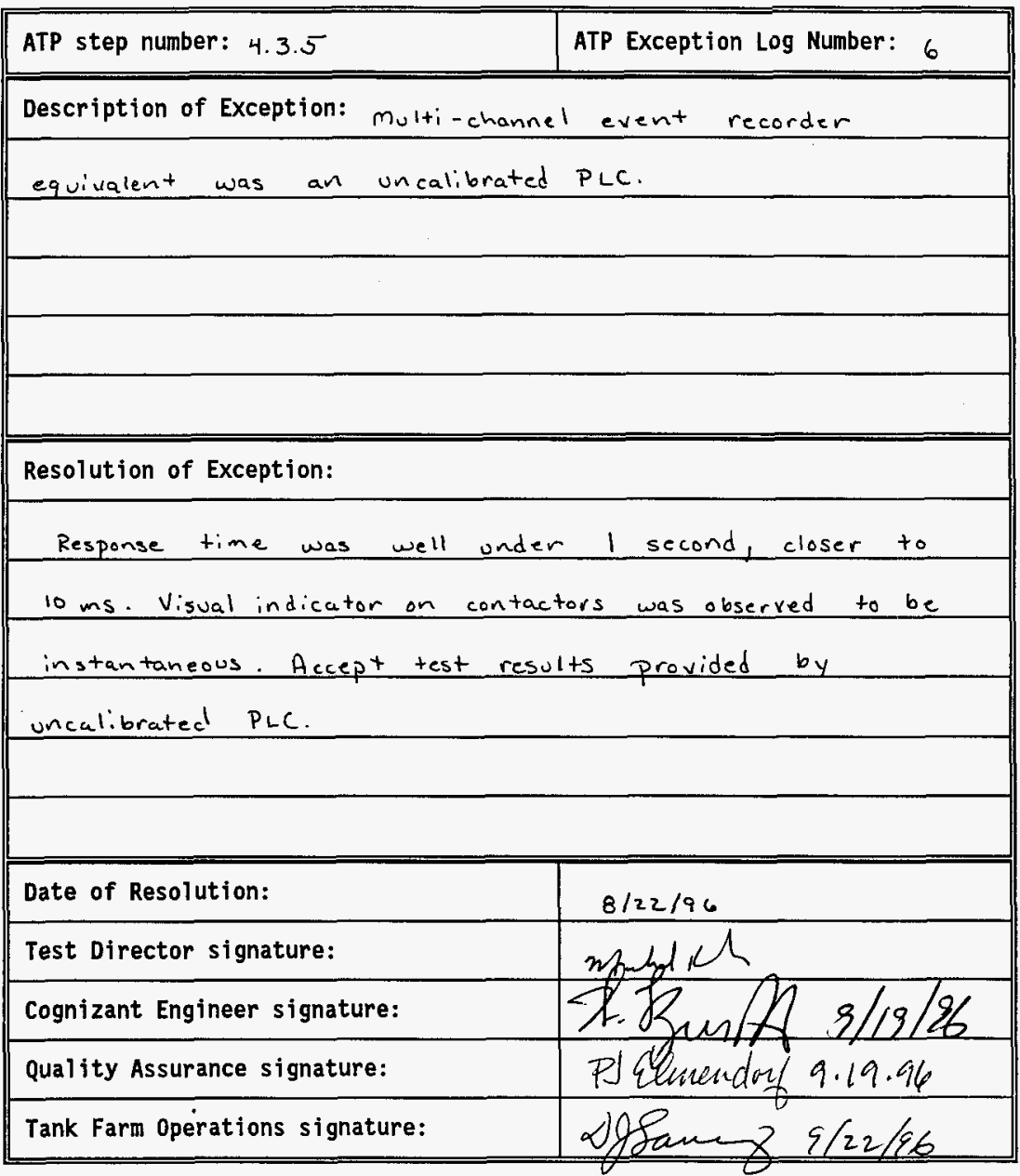




\section{ATP EXCEPTION RECORD}

This page may be reproduced as necessary.

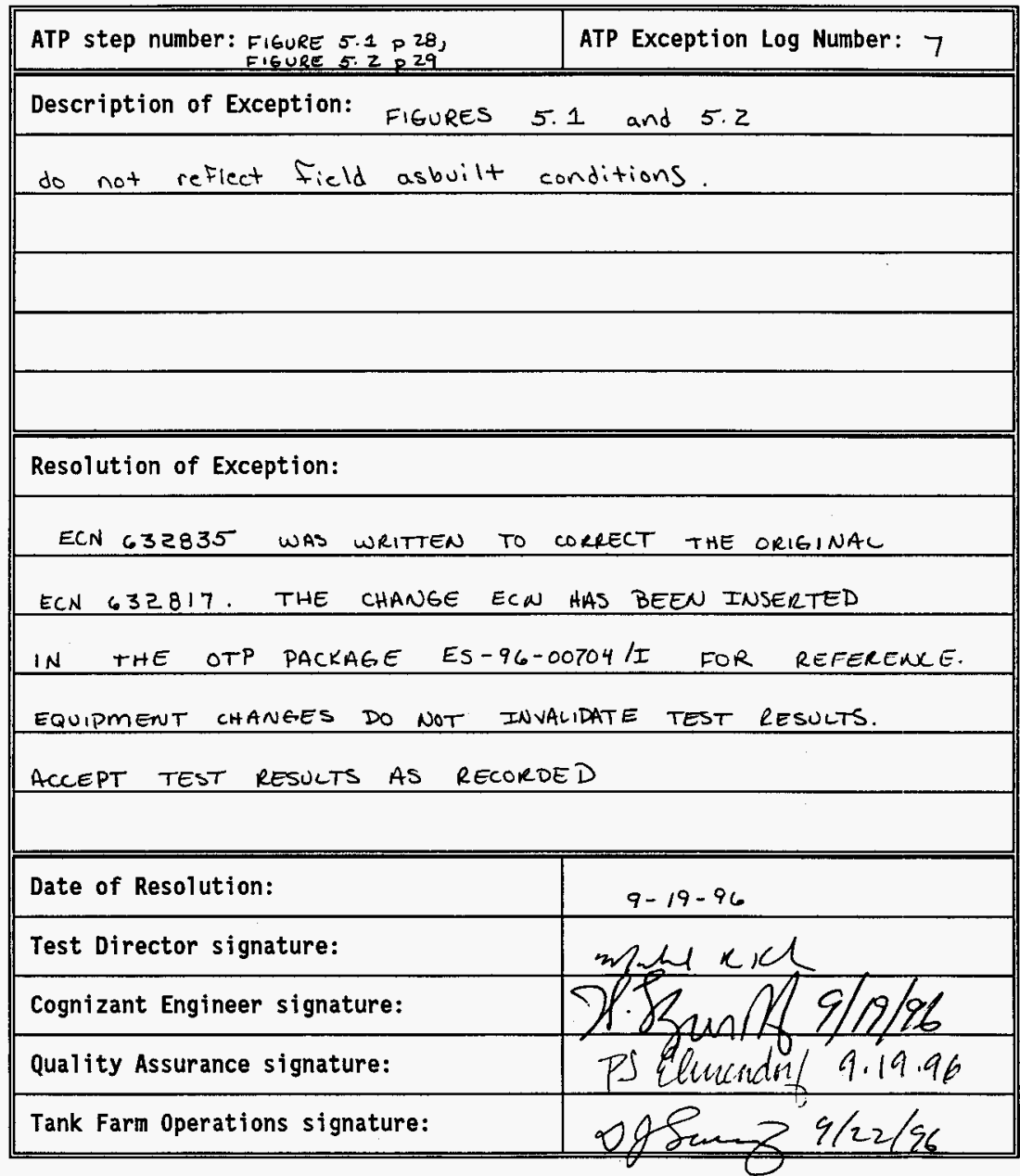


TANK FARM PLANT OPERATIONS PROCEDURE

ATP ACCEPTANCE RECORD

This ATP has been completed and the results, including red-1ine changes, exceptions, and exception resolutions, have been reviewed for compliance with the intent of the Purpose (Section 1.0). The ATP results are accepted by the undersigned:
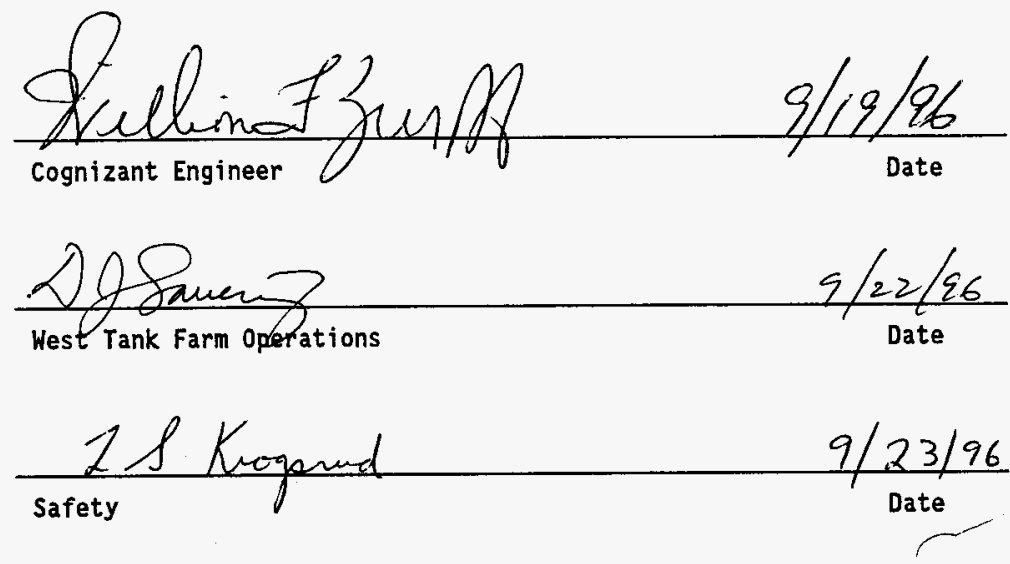

P) Gienuidal

$9 / 23 / 94$

\begin{tabular}{ll} 
Wheal KC & $8 / 22 / 46$ \\
\hline Test Director & Date
\end{tabular}

\begin{tabular}{|c|l|l|}
\hline Document No. & Page \\
WHC-SD-WM-ATR & 40 \\
\hline
\end{tabular}

